JOURNAL OF OPTIMIZATION, DIFFERENTIAL EQUATIONS AND THEIR APPLICATIONS (JODEA) Volume 26, Issue 1, June 2018, pp. 1-7, DOI 10.15421/141801

ISSN (print) 2617-0108 ISSN (on-line) $\mathrm{xxxx}-\mathrm{xxxx}$

\title{
STEPS TO THE FUTURE
}

\author{
Irina G. Balanenko*
}

\begin{abstract}
Historical milestones and directions of scientific research. To the 100th anniversary of the Oles Honchar Dnipro National University and the 52nd anniversary of the Department of Differential Equations
\end{abstract}

University is a special concept in the memory of many generations of people who have somehow connected their destiny with it. These people have showed the samples of diligence and honor, a high sense of duty and dignity, and devotion to the chosen case with their work, professional accomplishments and scientific discoveries, honest daily work. They have created the centenary chronicle of the alma mater, one of the most prestigious higher educational institutions in Ukraine.

Oles Honchar Dnipro National University today combines the best traditions of classical higher education, powerful potential of the world-famous research schools and modern trends in the introduction of innovative technologies.

The multi-volume history of the university created of human lives, personalities who began to form university traditions, determined the ways of further development, prepared a new generation of scholars that was so necessary for the development of the state has been made for 100 glorious, though difficult, years of our university.

Its glorious history goes back to 1918, when under the rule of Hetman Skoropadsky the Statute of Katerynoslav University was approved. The formation and growth of the university are closely connected with the names of such outstanding scholars as academicians L.V. Pisarzhevsky, A.N. Dynnyk, F.V. Taranovsky and D.I. Yavornytsky [1]. It is symbolic that the first educational building of the university was Prince Potiomkin's palace because the idea to set up an institution of higher learning in the city emerged when he was the governor of the region in the late 18th century. At that time Tsarina Catherine II issued an edict about the foundation of a university in Katerynoslav, "in which not only sciences but also arts are obliged to be taught".

Glimpses of DNU's glorious past reflect the dramatic history of the country in which the university has grown and gained firm standing and international recognition. About 30 research schools have sprung up here making the institution a leader in the university and academic science. Creation of a powerful trend in space engineering design in post-war years made DNU a unique classical university.

Pride and joy of the university are its alumni. Among those who emerged from the lecture halls of DNU are well-known writers Oles Honchar, Pavio Zahrebelny, Valerian Pidmohylny, academicians Serhiy Nikolsky, Volodymyr Mossakovsky,

\footnotetext{
* Department of Differential Equations, Oles Honchar Dnipro National University, Gagarin, av. 72, Dnipro, 49010, Ukraine, igb2008@i.ua

(C) I. G. Balanenko, 2018.
} 
Oleh Trubachov, Viktor Pylypenko, prominent political and public figures. Five of our alumni have been given the highest award of the country - the title of Hero of Ukraine. They are the renowned humanist of today Pavio Zahrebelny and famous space engineering designers who have created modern space image of our country: Stanislav Koniukhov, Yuri Alexeyev, Volodymyr Komanov and Volodymyr Sichovy [3].

Traditions of the past generations are being upheld and developed today by the researchers, teachers and students of the university. By the results of the polls among experts and students DNU hold a firm position in the annual "Sophia of Kyiv" rating competition among institutions of higher education of Ukraine and International exhibition "Modern Education in Ukraine" [6].

University's compliance with world educational standards has been recognized by the foreign colleagues. As of today there are about 50 bilateral cooperation agreements between DNU and leading educational and research institutions of Germany, France, Italy, Spain, Great Britain, Poland, Russia, Turkey, China, Brazil and the United States. Our university is an officially recognized regional leader by the quantity and quality of successfully realized international TEMPUS/ TASIS projects .

DNU is also a member of several international university associations, the most known of which are UNINET and "Eurasian Forum". Last year alone 47 foreign delegations, both educational and governmental, visited DNU. The university has become alma mater for alumni from 49 countries.

The history of the Dnipro National University would be incomplete without the history of the Department of Differential Equations.

A special fortune of the university, transforming it in September 1966 into one of the leading (under the terminology of that time - the basic) institution of higher education of Ukraine and the former Soviet Union, is quite rightly associated with the name of the academician, the Hero of the Socialist Labor, rector V. I. Mossakovskyi, who consistently headed the team for 22 years (19641986) [4].

As a basic institution, the university was assigned the role of a coordinating scientific and methodological center in the region. It became a kind of ground for innovations in the system of higher education. The new research laboratories and departments were created.

Department of differential equations was created in 1966 on the Mechanics and Mathematics Faculty of the Dnipropetrovsk State University. Associate Professor B. I. Kryukov headed by of the Department. Staff of the Department was as follows in 1966: Associate Professor B. I. Kryukov, Associate Professor V. A. Ostapenko, senior lecturer O. V. Zenkin, Assistant I. N. Shields, Assistant L. I. Shelest, senior laboratory L.V. Lybina.

The Laboratory of "Vibration Machines" (Head Assoc.Prof. E. A. Logvinenko) was organized at the Department in 1969. The study of the dynamics of vibration non-linear systems which are generating asymmetric vibrations were conducted in this Laboratory. The methods of calculation and design principles of new 
resonance vibration machines have been developed as a result. Here were designed, manufactured and introduced asymmetric vibration platforms, cluster plants, screen machines which allow to not only intensify the processes but the reduce the consumption of energy and materials and the fall of noise level up to sanitary standards. Division "Vibrational Technics" at the Department of Differential Equations was created with the aim of the implementation acceleration of the research results in 1971 [5].

A number of scientific and engineering organizations with priority of vibrational Technics were created in capital of USSR given the high economic efficiency of the new vibrational equipment, which was created the department staff, and the need the wide implementation into constructional industry of country. The government had decided to transfer of Prof. B. I. Kryukov, Assoc.Prof. E. A. Logvinenko (Head of Department), Ph.D. L. M. Litvin (Chief designer Department) as the heads of these organizations. At the end of the work (in 1979) these scientists were awarded the State Prize for the development of the theory of nonlinear systems, which are generating asymmetric vibrations, calculation methods and design principles of resonant vibration of machines and widespread adoption of scientific achievements in industry. All the theoretical and experimental studies were carried out at the Department of Differential Equations at the Dnepropetrovsk University.

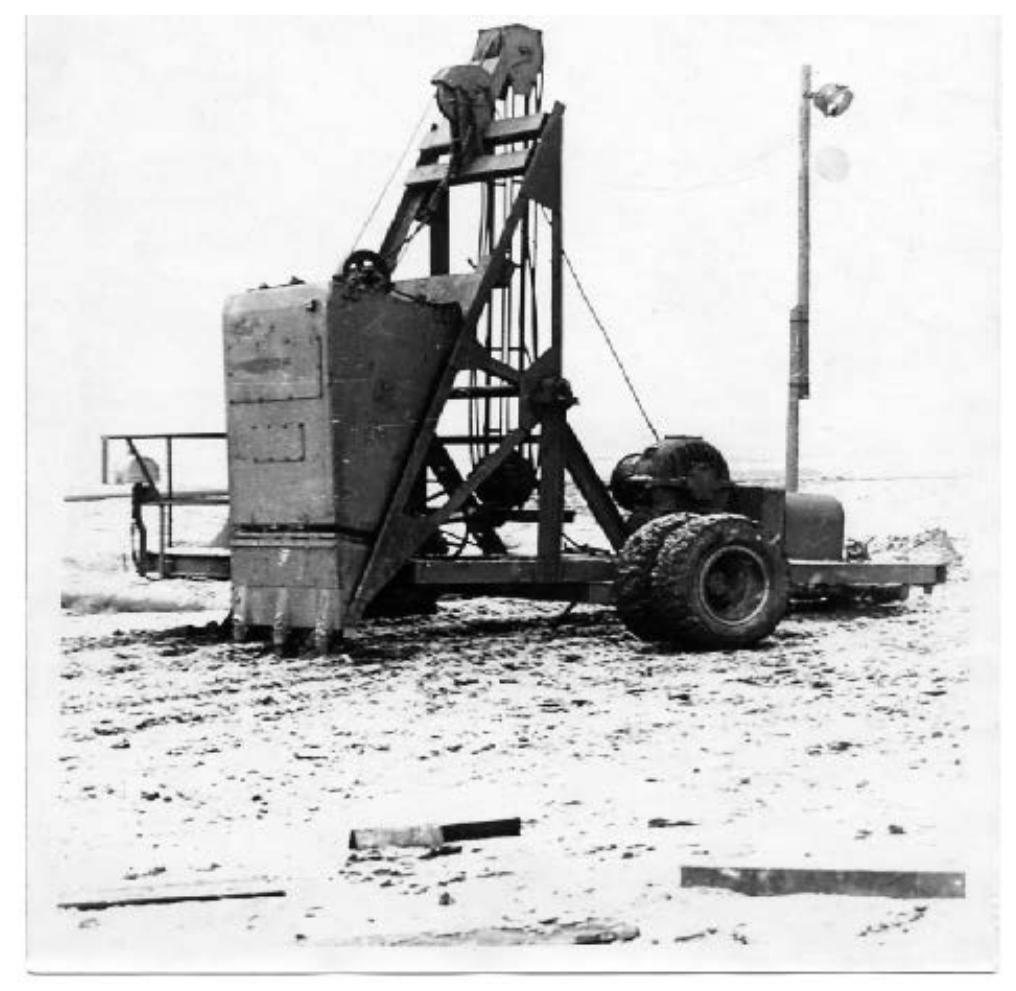

Fig. 1. Asymmetric vibration platform. 
In time the workload and the number of employees of the Department were increased. The skills of teachers are constantly improved. Professor V. A. Ostapenko (1975-1995), Professor N. V. Poliakov (1995-2014), Professor P. I. Kogut from 2014 (to the present) were headed the Department after Prof. B. I. Kryukov.

The present time of the native educational institution, its destiny, fame, achieve ments, outstanding scientific schools, well-known names in science and education, are closely connected with the people who studied and worked in it.

Prof. I. N. Shitov, Prof. V. A. Tychinin, Prof. M. V. Dmitriev, Assoc. Prof. V.I. Perechrest, Assoc. Prof. O. V. Zenkin, Assoc. Prof. G. I. Skorokhod, Assoc. Prof. V. B. Spivakovsky (Israel), Assoc. Prof. V. B. Kamen (USA), Assoc. Prof. T. V. Ridvanskaya, Assoc. Prof. A. A. Busurulov, Senior Lecture S. M. Ilyina, Assistant E. S. Mnouchkina, Assistant V. Z. Kachan, Assistant N. D. Pashkovskaya, Assistant S. A. Tyr worked at the Department at various times.

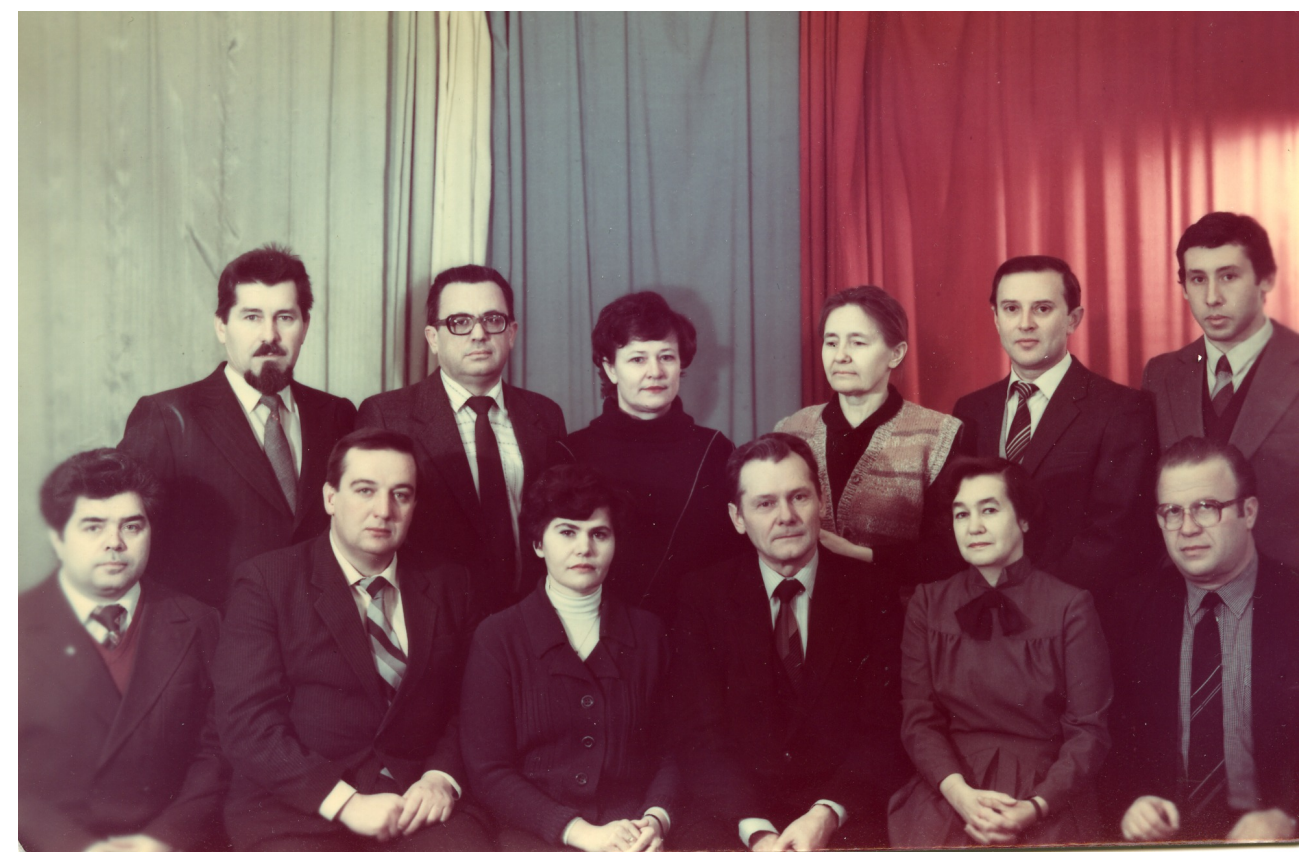

Fig. 2. Department of Differential Equations.

Since 1968 the scientific seminar "Differential equations and their applications" has worked at the department and a collection of scientific works with the same name has been published.

Among the research areas are the followings: the theory of diffraction and wave resonators, investigation of inverse problems for differential equations, investigation of gas-air tract of internal combustion engines, investigation of nonlocal and conditional symmetries of nonlinear equations of mathematical physics, setting and solving of inverse problems for differential equations, construction of exact solutions and asymptotic of solutions of nonlinear differential equations, solution 
of dynamic problems of the theory of elasticity, related problems of nonlinear thermoplasticity (two-phase problem), qualitative theory of differential equations, asymptotic methods in the theory of differential equations, mathematical modeling of dynamic systems, mathematical bases of the method of boundary integral equations, methods for solving incorrect problems.

Fundamental results were obtained in the directions:

- solving nonlinear boundary value problems of immersion of bodies in a liquid;

- asymptotic methods for solving nonlinear differential equations with partial derivatives;

- construction of new solutions of the Euler and Navier-Stokes hydrodynamic equations;

- integral images of problem solving for elliptic equations;

- solving inverse problems for differential equations with approximated coefficients;

- analytical solutions of boundary value problems for growing bodies, taking into account phase transitions.

Over the years the range of tasks was extended. The new problems were determined by the new needs of the national economy and the state, new scientific interests, the topics of contractual and state budget subjects of scientific research.

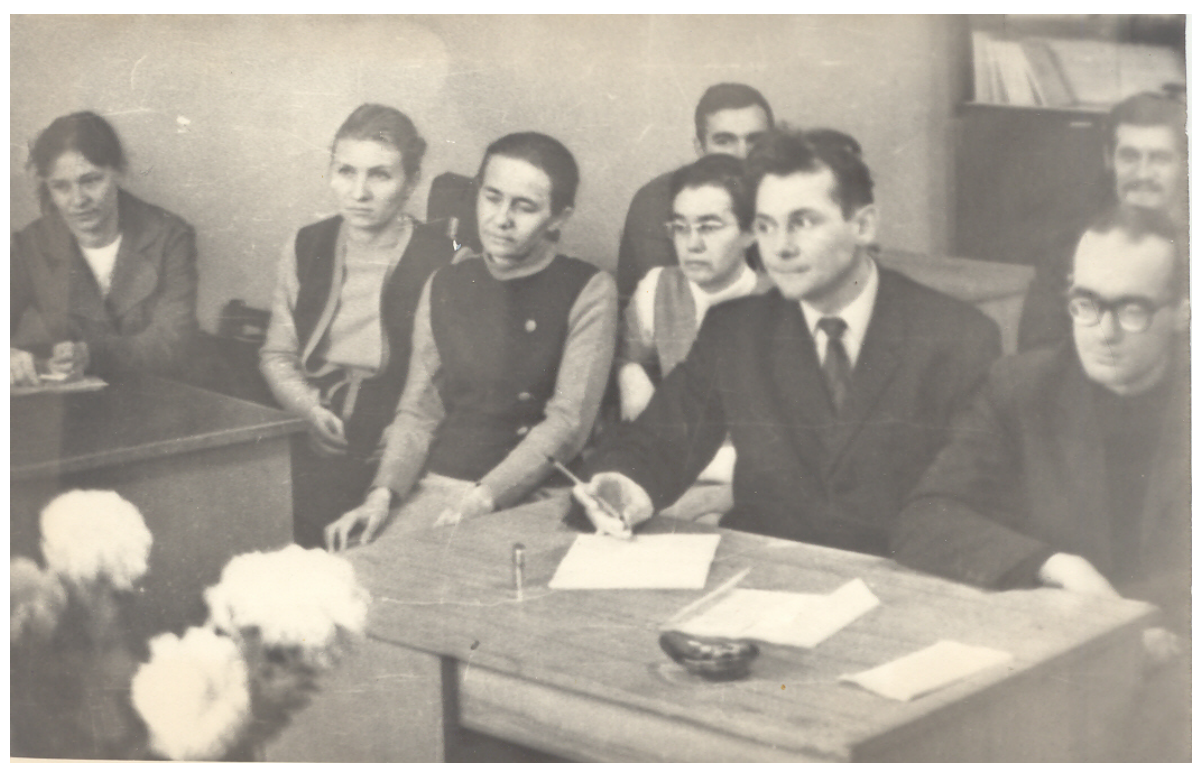

Fig. 3. The scientific seminar.

In 1997-1998 Department participated in scientific and applied research on the program "Sea Launch" together with the design department "Southern".

Five doctoral theses (V.A. Ostapenko, I.N. Shitov, M.V. Dmitriev, V.A. Tychinin, N.V. Poliakov) and 21 master's theses were protected since the establishment of the Department to the currently. 
Many graduates of the Department of Differential Equations became later teachers of the Dnipropetrovsk and other universities of Ukraine and other countries, and succeeded in various spheres of scientific and educational, economic and industrial, public and political life. More than 700 mathematicians have been trained by the Department for 50 years.

The university school of mathematical theory of controlled systems, aerohydromechanics and energy-mass transfer is well-known in Ukraine and abroad. The newest theories of differential equations are directly used for the creation of nanomaterials, solving problems of optimization of structures, calculating the dynamics of complex mechanical systems, solving environmental problems and filtration of systems with numerous microstructures, calculating the destruction of materials, and the creation of novel materials with predefined properties [5].

The Department has close educational and scientific links with the Institute of Mathematics of the National Academy of Sciences of Ukraine, the Kyiv National University, the Donetsk State University, the universities of Erlangen (Germany), Salerno (Italy), Naples (Italy), Bilbao (Spain), Moscow State University (Russia), Technical University of Cottbus (Germany), Lodz Polytechnic University (Poland) Technical University of Koblitz (Germany), as well as with universities in the USA, France, Israel and Russia.

Main scientific interests of the department now:

- Mathematical Modeling, Optimization and Control of Dynamical Systems and Processes in Science and Engineering;

- Optimal Control Problems for Partial Differential Equations with Control and State Constraints;

- Optimization of Traffic Flows on Networks;

- Optimal Control Problems for Nonlinear Hyperbolic Conservation Lows;

- Asymptotic Analysis of Optimization Problems on Reticulated Structures (perforated domains, thick multi-structures, thick junctions);

- Homogenization and Variational Convergence of Optimal Control Problems.

- Optimal Control Problems on Thick Periodic Graphs;

- Optimal Control Problems in Coefficients for Nonlinear PDE;

- Optimization Theory in Partially Ordered Normed Spaces;

- Inverse Problem Theory and Methods for Model Parameter Estimation;

- Exact and Approximate Methods of the Theory of Differential and IntegralDifferential Equations;

- Mathematical Modeling and Simulation of the Heat and Mass Transfer Processes with Nonequilibrium Relaxation.

On a regular base the department conducts the scientific seminar on "Modern Problems of Optimization and Mathematical Modeling" for research fellows, postgraduates, and senior students.

In 2013-2016 the research on the state budget subject "Modeling and optimization of nonlinear evolution systems" was conducted, since 2017 the research on the subject "Optimization of nonlinear systems with distributed parameters: qualitative analysis, approximation of solutions, necessary optimality conditions" has 
been carried out.

Staff of the Department now: Peter I. Kogut - Prof. Dr., Head of the Department, Mykola V. Poliakov - Corresponding Member of National Academy of Sciences of Ukraine, Prof. Dr., Professor, the Rector of Oles Honchar Dnipro National University, Andrii V. Siasiev - Ph.Dr., Associate Professor, Deputy Dean for Research of Faculty of Mechanics and Mathematics. Ph.Dr., Associate Professors: Vladimir L. Borsch, Marina V. Matyash, Yurii L. Menshikov, Eugene V. Turchin, Svitlana A. Gorbonos, Yurii P.Sovit, Olga S. Filippova, Eugene A. Makarenkov, Tamara A. Bozhanova, Irina G. Balanenko.

"The Bulletin of Dnipropetrovsk University. Series: Communications in Mathematical Modeling and Differential Equations Theory" is concerned with the theory and the application of partial differential equations, dynamical systems, optimal control theory and other related topics. The journal had been founded in 2009 . The goal is to provide a complete and reliable source of mathematical methods and results in this field. The journal will also accept papers from some related fields such as functional analysis, probability theory and stochastic analysis, inverse problems for differential equations, optimization, numerical computation, mathematical finance, game theory, system theory, etc., provided that they have some intrinsic connections with control theory and differential equations [6].

Since 2016 a collection of scientific works for students and postgraduates "Differential equations and their applications" is published.

We hope that "Journal of Optimization Differential Equations and Their Applications" will not only become the descendant of previous editions, but also provide an opportunity to broaden the range of issues to be solved and the geography of its authors and readers.

\section{References}

1. M. V. Poliakov, V.S. Savchuk, Classical University: from ideas of antiquity to ideas of the Bologna process, DNU Publishing House, Dnipropetrovsk, 2010.

2. М. В. Поляков, На бистрині життл, Д.: АРТ-ПРЕС, 2016.

3. О.В. ГонЮК, В. В. Іваненко, І. С. ПоПовА, Славетне сузір'я окрилених університетом: [нариси], Д.:Вид-во ДНУ, 2008.

4. І Історія Дніпропетровського начіонального університету, Голова редколегії проф. М. В. Поляков, 4-те вид., переробл. і доповн. Д.:Вид-во ДНУ, 2008.

5. Н. В. Поляков, Ю. Л .МЕньшиков, Г. И. Скороход, Профессор Остапенко Виктор Александрович - механик, математик, педагог, Вістник ДНУ, Серія: Моделювання , Дніпропетровськ: ДНУ, вып.5, № 8, , 2013, 3--30.

6. $\quad$ Past and present. - http://www.dnu.dp.ua. 